\title{
МОРФОЛОГІЧНІ ЗМІНИ В ОРГАНАХ ЩУРІВ ЗА КОМБІНОВАНОЇ ДІЇ СОЛЕЙ ВАЖКИХ МЕТАЛІВ ТА ФОСФОРОРГАНІЧНИХ ПЕСТИЦИДІВ
}

Вступ. Отруєння свинцем є небезпечним для здоров'я населення. Свинець і його сполуки використовують у промисловості для виготовлення фрарб, емалей та ін., тому одним з основних шляхів потрапляння свинцю в організм людини є вдихання пилу і диму його сполук. Свинець проявляє імунотоксичність, викликає ураження печінки, нирок, органів дихання, кровоносної та нервової систем.

Мета дослідження - вивчити вплив Плюмбуму ацетату, Купруму сульфрату і гліфросату у фрормі раундапу на морфологічні зміни в тканинах серця, нирок та печінки щурів різного віку.

Методи дослідження. Досліди проводили на лабораторних нелінійних білих щурах-самцях трьох вікових періодів: статевонезрілих (молодих масою 70-90 г і віком 1-3 міс.), статевозрілих (дорослих масою 170-210 г і віком 5-8 міс.), старих (масою 250-300 г і віком 20-24 міс.), яким внутрішньошлунково протягом 30-ти днів вводили водні розчини Плюмбуму ацетату, Купруму сульфрату і гліфосату (у фрормі гербіциду раундапу) та виконували корекцію пептидом цистеїл-гістидил-тирозил-гістидил-ізолейцином. Гістологічні препарати вивчали після забарвлення їх гематоксиліном та еозином за допомогою світлового мікроскопа OLYMPUS “CX 21".

Результати й обговорення. Встановлено, що введення тваринам водних розчинів Плюмбуму ацетату, Купруму сульфрату і раундапу впливає на фрункції їх органів. Під час морфрологічних досліджень було виявлено клітинні ураження в тканинах серця, нирок та печінки щурів, викликані введенням ксенобіотиків. Гістологічні ураження включали запалення, гіперхромну анемію, поліморфнну інфрільтрацію клубочків та клітинну дегенерацію нирок і печінки. Спостерігали дистрофрію паренхіматозних клітин, некротичні процеси та застійні явища в серці, нирках і печінці всіх піддослідних тварин.

Висновок. Введення Плюмбуму ацетату, Купруму сульфрату і гліфосату у формі раундапу викликає морфологгічні зміни в тканинах серця, нирок та печінки щурів.

КЛЮЧОВІ СЛОВА: морфофрункціональні властивості; Плюмбуму ацетат; Купруму сульфат; гліфосат; хронічна дія; щури.

ВСТУП. Свинець - важкий метал, який використовують у багатьох галузях промисловості, тому є одним із забруднювачів навколишнього середовища. Він розподіляється у всіх частинах навколишнього середовища (повітрі, воді, ґрунті) та існує в трьох основних фрормах: металевий свинець, в органічних (тетраетилсвинець) і неорганічних (Плюмбуму ацетат, Плюмбуму хлорид) сполуках [1]. Свинець впливає на організм людини переважно через дихальну систему та шлунково-кишковий тракт. Він поглинається шкірою. Незалежно від шляху потрапляння в організм свинець накопичується і зберігається в м'яких тканинах печінки. Незначна частина його сполук у печінці перетворюється в кон'югати і виділяється із сечею, а решта - накопичується в різних органах тіла [2].

Свинець викликає морфологічні зміни у всіх органах, зокрема серці, нирках і печінці. При дії (с) Є. Б. Дмухальська, 2019. його солей у серцево-судинній системі переважають порушення резистентності перисреричних судин, серцевого викиду і частоти серцевих скорочень. Низькі дози свинцю можуть викликати гіпертензію, ішемічну хворобу серця як у людей, так і у тварин, при цьому порушують тонус гладких м'язів судин, що знижує активність Na-K-АТФ-ази та підвищує рівень внутрішньоклітинного кальцію [3].

У нирках сполуки свинцю можуть спричинити нефропатію, гломерулонефрит і морфологічні зміни органа, що призводять до гіперурії, гіпертензії та ниркової недостатності [4]. Гепатотоксичність свинцю пов'язана з підвищеною активністю в сироватці крові аланін- та аспартатамінотранссрераз, утворенням активних форм Оксигену та порушенням метаболізму холестеролу в печінці [5].

Не менш токсичними для людини є пестициди. Пестициди (сільськогосподарські отруто- 
хімікати) - хімічні засоби, які використовують для боротьби зі шкідниками і хворобами рослин, а також із різними паразитами, бур'янами, шкідниками зерна та зернопродуктів, деревини, виробів з бавовни, вовни, шкіри, ектопаразитами домашніх тварин, переносниками небезпечних захворювань людини і тварин. Потрапляючи в організм людини, вони викликають порушення фрункції серцево-судинної, нервової, видільної систем, шлунково-кишкового тракту та інших органів і систем [6].

Мета дослідження - вивчити вплив Плюмбуму ацетату, Купруму сульфрату і гліфосату у формі раундапу на морфологічні зміни в тканинах серця, нирок та печінки щурів різного віку.

МЕТОДИ ДОСЛІДЖЕННЯ. Морфологічні зміни в печінці, нирках, серці тварин при комбінованій дії Плюмбуму ацетату, Купруму сульфрату, гліфосату вивчали на лабораторних нелінійних білих щурах-самцях трьох вікових періодів: статевонезрілих (молодих масою 70-90 г і віком 1-3 міс.), статевозрілих (дорослих масою 170210 г і віком 5-8 міс.), старих (масою 250-300 г і віком 20-24 міс.).

Інтоксикацію в щурів викликали шляхом щоденного перорального введення впродовж 30-ти діб водних розчинів Плюмбуму ацетату в дозі 11 мг/кг маси тіла (1/20 LD 50 , Купруму сульфрату в дозі 13 мг/кг маси тіла (1/20 LD 50 ), гліфросату (у формі гербіциду раундапу) в дозі 250 мг/кг маси тіла $\left(1 / 20 L_{50}\right) .3$ метою корекції виявлених порушень на 21-й день експерименту через 6 год після введення токсикантів щодня протягом 10-ти днів вводили внутрішньошлунково пептид цистеїл-гістидил-тирозил-гістидил-ізолейцин у дозі 9 мг/кг маси тіла (концентрація амінокислот у крові). Як контроль використовували інтактних щурів відповідного віку, яким вводили питну водопровідну дехлоровану воду.

Тварин усіх вікових періодів було поділено на такі групи: 1-ша - інтактні (контрольні); 2-га тварини, одночасно уражені всіма вищеперерахованими токсикантами; 3-тя - щури, яким проводили корекцію пептидом. На 31-шу добу після останнього введення ксенобіотиків та чинників корекції тварин виводили з експерименту за умов тіопентал-натрієвого наркозу.

Під час проведення досліджень усі щури перебували у віварії Тернопільського державного медичного університету імені І. Я. Горбачевського на стандартному раціоні відповідно до санітарно-гігієнічних норм. Утримували щурів та проводили всі експерименти на них із дотриманням національних (Закон України № 3447-IV "Про захист тварин від жорстокого поводження", 2006) та міжнародних (Європейська конвенція про захист хребетних тварин, що використовуються для дослідних та інших наукових цілей, Страсбург, 1986) загальних правил і рекомендацій щодо гуманного поводження 3 лабораторними тваринами [7-9].

Органи для дослідження забирали віддразу після евтаназії та фріксували в 10 \% розчині нейтрального фрормаліну. При виконанні морфологічних досліджень було використано загальноприйняті гістологічні методики [10]. Гістологічні препарати вивчали після забарвлення гематоксиліном та еозином за допомогою світлового мікроскопа OLYMPUS "CX 21" при збільшенні в 160 та 320 разів. Найбільш демонстративні гістологічні препарати фротографували за допомогою відеокамери "VISION Color CCD Camera" із застосуванням програми "Inter Video Win DVR".

РЕЗУЛЬТАТИ Й ОБГОВОРЕННЯ. Мікроскопічне дослідження міокарда статевонезрілих уражених ксенобіотиками тварин показало насамперед суттєві порушення гемодинаміки, які стосувалися всіх ланок гемоциркуляторного русла. Так, у капілярах на поздовжніх зрізах маніфестували ознаки стазу - феномен "монетних стовпчиків". Спостерігали системну дилатацію венозного коліна. Різко розширені просвіти венул та дрібних вен були заповнені кров'ю. Поряд із цим відзначали явні прояви порушення реологічних властивостей крові - стаз і сладж еритроцитів, їх пристінкову агрегацію. Подекуди еритроцити просякали судинну стінку, фрормуючи невеликі перивазальні крововиливи. В артеріальній ланці виникали подібні зміни, але вони мали переважно локальний характер. Стінки артеріол і дрібних артерій потовщувалися за рахунок плазматичного просякання, яке, у свою чергу, зумовлювала патологія ендотеліальної вистілки. Ендотеліоцити набували округлої фрорми, випинали в просвіт судин. На багатьох ділянках злущені клітини наповзали одна на одну, "оголюючи" базальну мембрану та створюючи передумови для плазморагії (рис. 1).

Паралельно описані зміни поєднувалися 3 поліморфноклітинною чи лімфоцитарною інфрільтрацією судинних стінок.

Інтерстиціальна тканина міокарда, особливо навколо судин, потовщувалася і набрякала. Транссудації рідини в цьому випадку сприяли застій крові та збільшення проникності судинної стінки на тлі гіпоксії. Набряк мав тенденцію до поширення на міжклітинну строму. Проте слід зауважити, що на багатьох ділянках досліджуваних зрізів виявляли колапс строми.

Найбільших структурних змін зазнавав скоротливий апарат міокарда молодих щурів - кардіоміоцити. У місцях їх компактного розміщення 
межі клітин розмивалися та нечітко розрізнялися. Цитоплазма забарвлювалася нерівномірно, що надавало загальній гістологічній картині мозаїчного характеру. Поперечна посмугованість слабо розрізнялася, була переривчастою або повністю відсутньою. Нерівномірно забарвлена цитоплазма мала зернистий вигляд. Часто зерна зливалися у грудочки різного розміру, а сама цитоплазма розпадалася. На поздовжніх зрізах чітко спостерігали хвилеподібну деформацію кардіоміоцитів та осередкову фррагментацію (рис. 2).

У зонах найбільшого ушкодження виявляли поліморфноклітинні інфрільтрати. При таких структурних змінах саркоплазма ядра теж характеризувалася поліморфізмом: на просторих ділянках візуалізувалися пікнотичні ядра, зрідка вони були відсутні.

Дослідження структурної організації тканини нирок молодих щурів також показало наявність суттєвих патоморфологічних порушень як стромальних, так і паренхіматозних компонентів. Маніфестували розлади кровообігу, активно реагувало мікроциркуляторне русло, судини якого дилатували та були переповнені кров'ю. Приєднувалися ознаки порушення гемореології - стаз та сладж еритроцитів. Однак ці прояви не були системними. У межах одного органа ділянки повнокров'я чергувалися 3 ділянками зниженого кровонаповнення. У тварин цієї групи розлади гемодинаміки набували характеру шокових: судини кіркового шару ставали різко малокровними, судини мозкового шару, зокрема пірамід, - різко повнокровними, аж до геморагічного просякання стінок судин. Такі гемодинамічні порушення супроводжувалися вираженим стромальним набряком. Клубочки мали різний розмір, що було зумовлено рівнем їх кровонаповнення і станом мезангіуму. Клубочки з повнокровними капілярами та розширеним набряком мезангіуму займали весь простір капсули Шумлянського - Боумена. Інші клубочки колабували (рис. 3).

Найглибші структурні зміни спостерігали зі сторони паренхіматозного компонента нефронів. Можна думати, що ушкодження виникло внаслідок поєднання прямого токсичного впливу та опосередкованого гіпоксичного ураження. Але навіть у межах одного органа ці зміни різнилися за своєю інтенсивністю. Так, у багатьох полях зору епітеліоцити різко набухали, перекриваючи просвіти канальців. При цьому їх цитоплазма ставала зернистою або розпадалася на грудочки. В інших місцях апікальна десквамація призводила до розширення просвітів канальців. Часто в таких розширених просвітах містилися зернисті чи аморфні еозинофрільні маси. Нерідко клітини були відділені від базальної мембрани й одна від одної. У деяких випадках клітини втрачали чіткі контури, цитоплазма вакуолізовувалась, ядра ледве контурувалися або були відсутні, зрідка - пікнотичні. Місцями такі зміни супроводжувалися тубулорексисом (рис. 4).

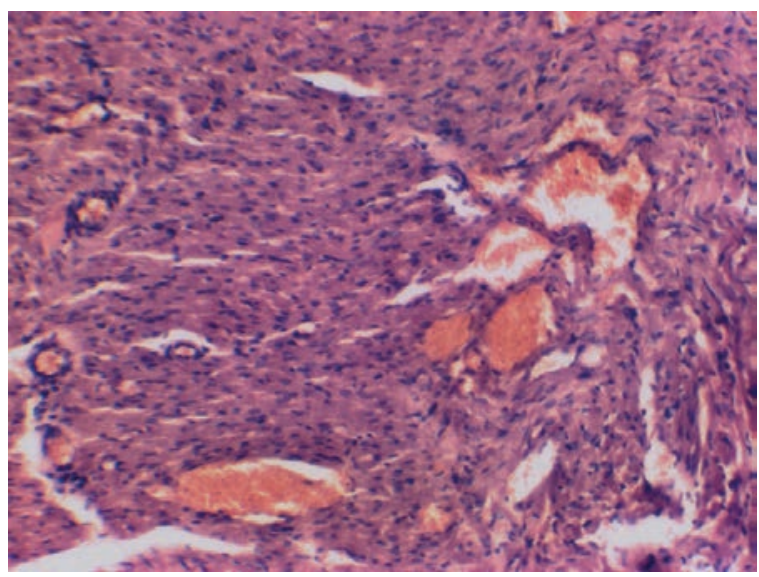

Рис. 1. Дилатація і повнокров'я судинного русла міокарда статевонезрілого щура, сладж та пристінкова агрегація еритроцитів. Забарвлення гематоксиліном та еозином. Ок. 10. Об. 20.

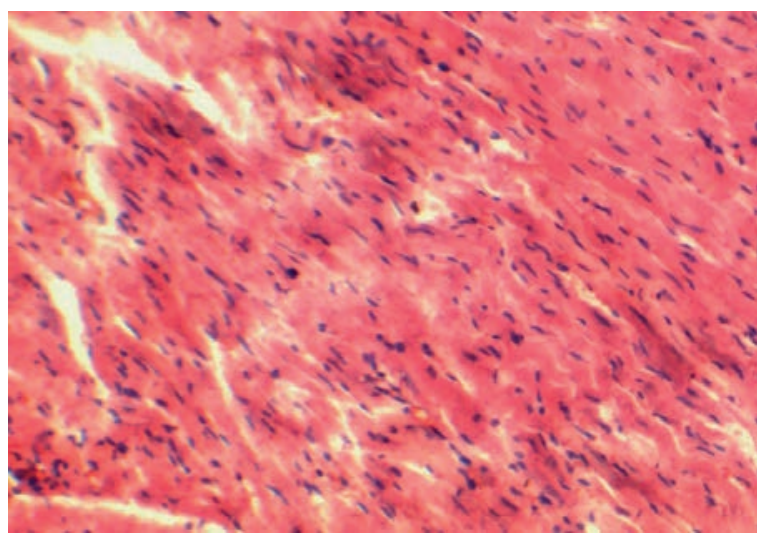

Рис. 2. Хвилеподібна деформація ходу кардіоміоцитів, осередкова фррагментація і глибковий розпад цитоплазми в міокарді статевонезрілого щура. Забарвлення гематоксиліном та еозином. Ок. 10. Об. 20.

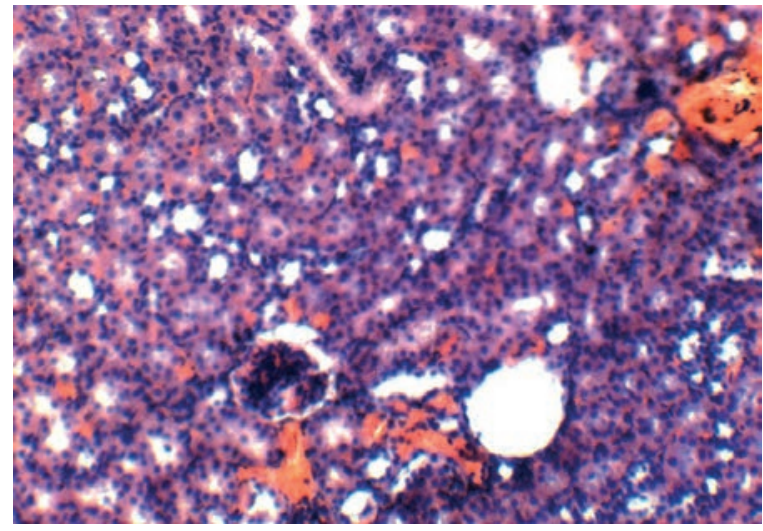

Рис. 3. Гіперемія дилатованих судин кіркового шару нирки статевонезрілого щура. Забарвлення гематоксиліном та еозином. Ок. 10. Об. 20. 
Загальна характеристика світлооптичних змін паренхіми печінки і судинного русла в цілому була аналогічною. Мікроскопічне дослідження печінки молодих щурів виявило суттєві патоморфрологічні зміни всіх її структурних компонентів. Капілярно-судинне русло у всіх досліджуваних випадках було нерівномірно кровонаповнене 3 переважанням повнокров'я його венозної ланки та з вираженими ознаками порушення реологічних властивостей крові: стазом, перерозподілом фрормених елементів, склеюванням еритроцитів (сладж-ореномен). Перисинусоїдальні простори розширювалися (рис. 5). У багатьох випадках дилатація та гіперемія артеріально-венозного русла мали системний характер.

Змінювалася гістоархітектоніка печінкових часточок, що проявлялося втратою їх характерної балково-радіальної структури та дискомплексацією печінкових клітин. Особливу увагу привертали зміни гепатоцитів. Дистрофрічні зміни виникали в усіх печінкових клітинах, але ступінь вираження ушкодження був різний як у межах цілого органа, так і в межах окремих часточок. Якщо в центрах часточок архітектоніка зберігалася, а клітини наближалися до інтактних, то в перифреричних відділах спостерігали повну дискомплексацію печінкових балок, що створювало френомен "бруківки". Гепатоцити тут мали різний розмір, однак значна кількість була збільшена в об'ємі, їх нерівномірно забарвлена цитоплазма містила ацидофільні білкові гранули, які мали тенденцію до злиття в більші білкові включення. Мембрани гепатоцитів втрачали чіткість контурів, межі їх зливались. Ядра печінкових клітин також були виразно поліморфними та нерівномірно забарвленими за рахунок нерівномірного розподілу хроматину. Центролобулярно візуалізувалися гіпертрофовані гепатоцити 3 двома ядрами, що свідчило про компенсаторний характер їх змін. Частина клітин збільшувалася в об'ємі через вакуолізацію цитоплазми поряд із добре вираженими контурами мембран. Залишки слабоеозинофрільної зернистої цитоплазми розміщувалися навколо ядра або вздовж мембрани. Ядра мали бліде забарвлення з ознаками каріорексису та каріолізису (рис. 6). Загалом внаслідок описаних змін створювався ефект оптично порожньої цитоплазми.

Окремі клітини розпадалися на фррагменти без перисрокальної клітинної реакції. Зрідка в стінках судин і стромі портальних трактів спостерігали дрібні поліморфноклітинні інфрільтрати.

У міокарді дорослих щурів, уражених Плюмбуму ацетатом, Купруму сульфатом і гліфосатом (у фрормі гербіциду раундапу), ми спостерігали зміни, подібні за морфологічними характеристи-

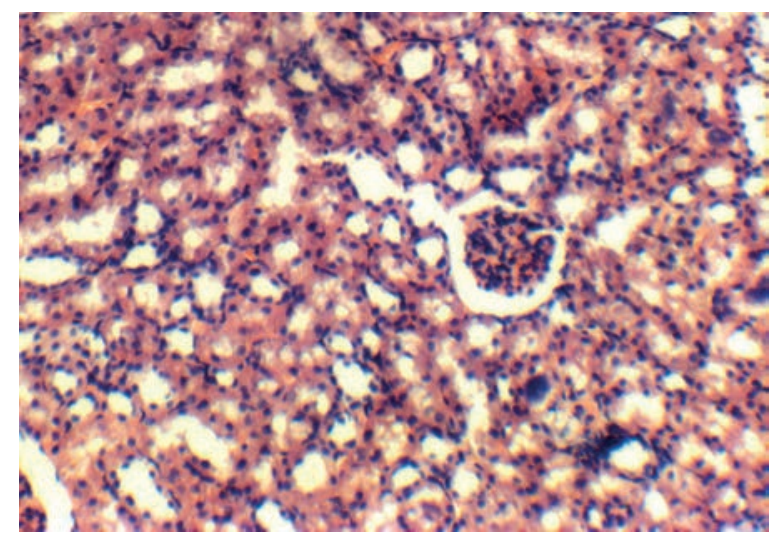

Рис. 4. Вакуольна дистрофрія епітелію дистальних і проксимальних канальців нирки статевонезрілого щура. Забарвлення гематоксиліном та еозином. Ок. 10. Об. 20.

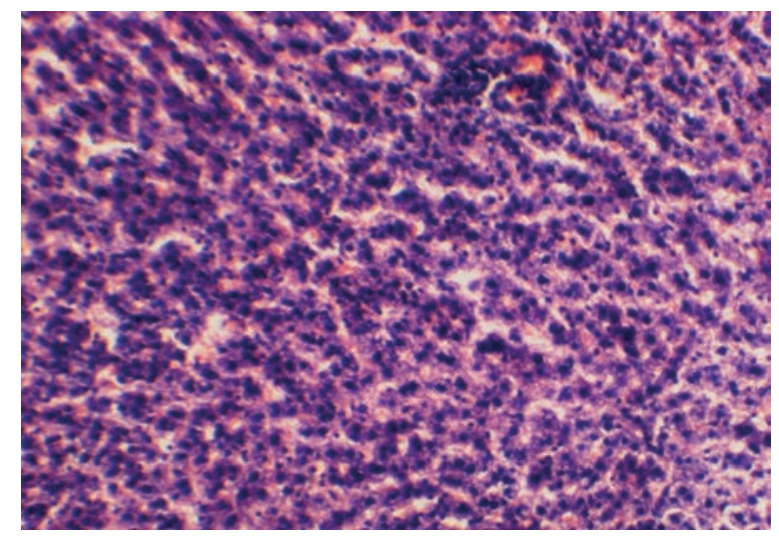

Рис. 5. Дифузне повнокров'я синусоїдних капілярів, розширення просторів Діссе, білкова дистроорія гепатоцитів. Печінка статевонезрілого щура. Забарвлення гематоксиліном та еозином. Ок. 10. Об. 20.

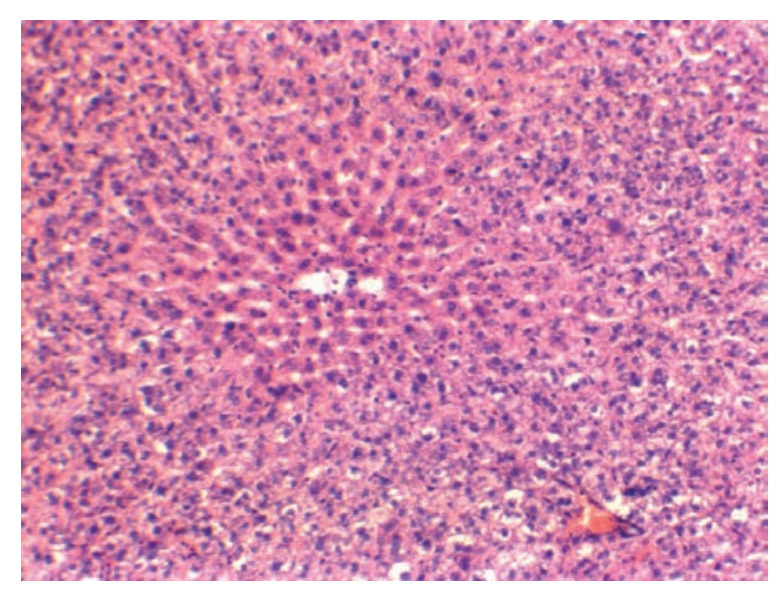

Рис. 6. Дискомплексація і вакуольна дистрофрія гепатоцитів у периореричних відділах часточок. Печінка статевонезрілого щура. Забарвлення гематоксиліном та еозином. Ок. 10. Об. 10.

ками до виявлених у групі статевонезрілих тварин. Однак поширеність їх та глибина ураження були суттєво меншими. Гемодинамічні розлади мали місце, але на їх тлі зустрічалися судини зі збереженим тонусом, що візуально змінювало характер кровонаповнення міокарда. Явища паретичного повнокров'я були меншими за по- 
ширеністю. Відповідно, на таких ділянках виявляли і порушення гемореології у вигляді стазу крові, склеювання еритроцитів та відсепаровування рідкої частини крові. Стромальний набряк маніфестував саме в цих місцях, тому інтерстицій розрихлювався нерівномірно. Зрідка стан кровоносної системи наближався до нормального.

Незважаючи на токсичний вплив, часткове збереження адекватного кровотоку сприяло покращенню стану серцевого м'яза в цілому. В групі дорослих тварин ми не спостерігали деструктивних змін кардіоміоцитів із клітинною реакцією строми в ділянках ушкодження. Кардіоміоцити переважно зберігали компактне і впорядковане розміщення. Однак дистрофрічні зміни клітин були дифузними. При відсутності фррагментації та глибкового розпаду тинкторіальні властивості цитоплазми змінювалися - відзначали нерівномірне забарвлення (рис. 7). Неоднорідність міокарда посилювалася також за рахунок нерізко вираженої поліморфності ядер.

При мікроскопічному дослідженні нирок дорослих щурів ми спостерігали більш рівномірне кровонаповнення клубочків та судин кіркового і мозкового шарів порівняно $з$ групою молодих тварин. Однак зберігались ознаки змінених реологічних властивостей крові: стаз, сладж-феномен. Такі зміни сприяли збереженню стромального набряку.

Клубочки мали чіткі обриси та був добре виражений просвіт капсули Шумлянського - Боумена. Епітеліальна вистілка канальцевого апарату теж мала більш структурований вигляд при наявності білкової дистрофії на різних стадіях: мутне набухання клітин, зернистість, зрідка вакуолізація цитоплазми.

У жодному випадку не спостерігали деструктивних змін базальної мембрани в кірковому шарі нирки (рис. 8). Аналогічні зміни відбувалися і в мозковому шарі досліджуваних нирок.

Патогістологічні зміни при світлооптичному аналізі тканини печінки за своїм вираженням корелювали зі структурними проявами в міокарді та нирках тварин цієї групи. Повнокров'я 3 явищами стазу проявлялося переважно центролобулярно. Перисинусоїдні простори були розширеними. На тлі таких змін чітко візуалізувалася збережена гістоархітектоніка часточок. Однак у всіх випадках дистрофрічні зміни печінкових клітин були достатньо вираженими. Вони проявлялися в дифузній формі, поширюючись на всю часточку, або займали тільки окремі ії зони, переважно по перифрерії часточок.

Печінкові клітини нерівномірно фрарбувалися гематоксиліном та еозином, що створювало картину мозаїчності забарвлення: світлі ділянки чергувалися з більш темними, в цитоплазмі спостерігали дрібну білкову зернистість. Білкові зерна мали тенденцію до злиття в більші гранули. Нерідко окремі гепатоцити та їх групи містили вакуолізовану цитоплазму (рис. 9).

Мікроскопічний аналіз морфологічних змін внутрішніх органів старих тварин, уражених

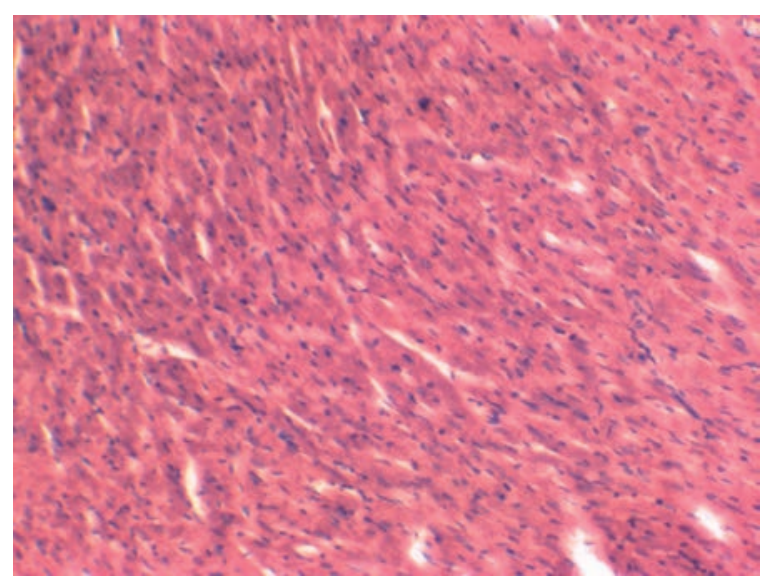

Рис. 7. Дифузні помірно виражені дистрофічні зміни і набряк строми міокарда дорослого щура. Забарвлення гематоксиліном та еозином. Ок. 10. Об. 20.

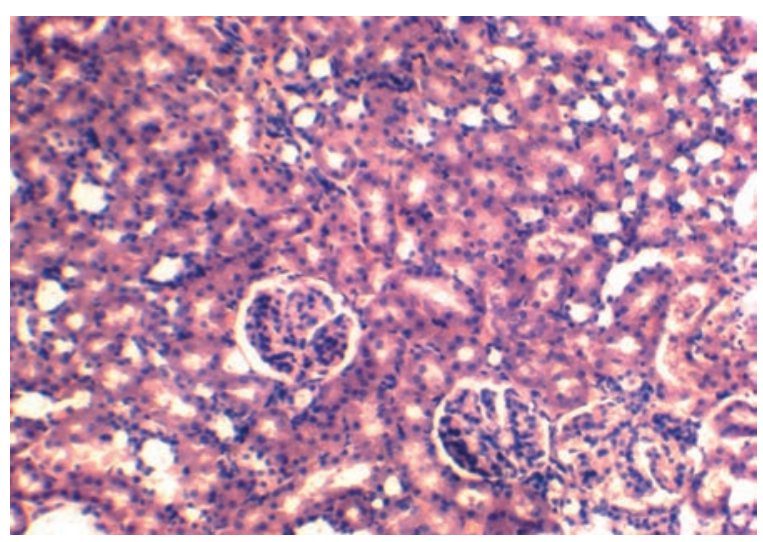

Рис. 8. Кірковий шар нирки дорослого щура. Помірна білкова дистросрія епітелію проксимальних і дистальних відділів канальців. Клубочки чітко структуровані. Забарвлення гематоксиліном та еозином. Ок. 10. Об. 20.

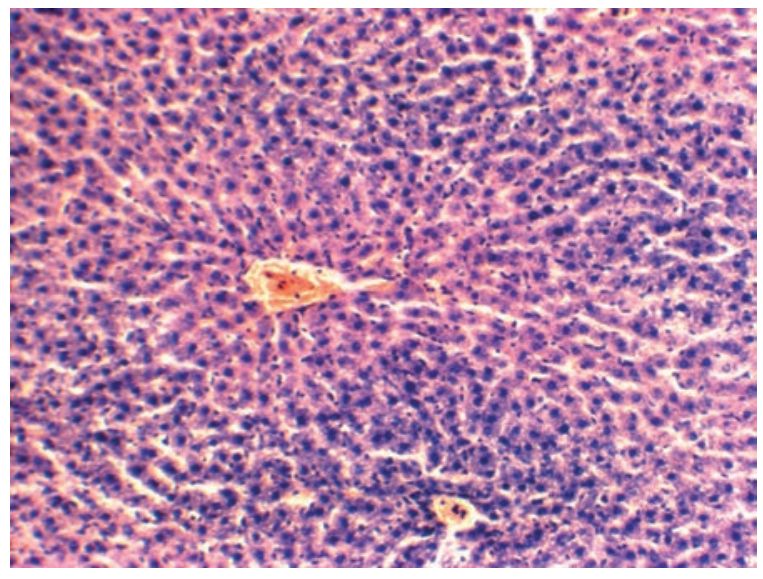

Рис. 9. Гістологічні зміни печінки дорослого щура. 3абарвлення гематоксиліном та еозином. Ок. 10. Об. 10. 
Плюмбуму ацетатом, Купруму сульсратом і гліфосатом (у формі гербіциду раундапу), показав їх максимальну наближеність до змін у молодих щурів.

У міокарді уражених старих щурів при розладах кровообігу переважала дилатаційна гіперемія судин венозної ланки мікроциркуляторного русла та капілярів. Сповільнення кровотоку сприяло сладжу еритроцитів та їх гемолізу, відсепаровуванню плазми, просяканню ії як у судинні стінки, так і перивазально. Тому периваскулярний набряк був характерний у цій дослідній групі. Звертало на себе увагу значне потовщення стінок артеріол та деяких дрібних вен, яке було зумовлене кількома фракторами, перш за все внутрішньостінковими плазморагіями та круглоклітинною інфрільтрацією. Ці гострі порушення нашаровувалися на склеротичні зміни судинних стінок (рис. 10). Місцями фріброзні мусрти оточували судини, вмуровуючи їх у масив кардіоміоцитів.

У зонах набряку кардіоміоцити локалізувалися розрізнено, часто порушувалися їх орієнтація та цілісність - спостерігали ділянки хаотичного і хвилеподібного розташування клітин, фррагментації. Поперечної посмугованості не спостерігали. Якісних змін зазнавала цитоплазма, яка погано і нерівномірно вбирала барвник, ставала гетерогенною. У ній виявляли осередки глибкового розпаду цитоплазматичного матриксу, зрідка - вакуолізації. Ядра були різного розміру. В окремих кардіоміоцитах та їх групах ядра не візуалізувалися. На ушкодження строма реагувала формуванням поліморфних клітинних інорільтратів. На поздовжніх зрізах серцеві міозити виглядали переривчастими та мали нерівномірну товщину (рис. 11).

У нирках старих щурів ми виявили морфологічні зміни, подібні до вже описаних у молодих тварин. Окремо слід зауважити, що при аналогічних гемодинамічних порушеннях дистрофічно-дегенеративні зміни паренхіматозного компонента нефронів мали тенденцію до розширення зон ураження (рис. 12).

Світлооптичне дослідження печінки старих тварин також показало наявність виражених структурних порушень. Гемоциркуляторні порушення були ідентичними з описаними в молодих і дорослих щурів, але привертало увагу більш інтенсивне та рівномірне повнокров'я. Подекуди з потовщених портальних трактів у паренхіму вростали тонкі сполучнотканинні септи. Спостерігали інсрільтрацію лімсоцитами та гістіоцитами (рис. 13). Зони дискомплексації займали по кілька полів зору і поширювалися на всю часточку. Гепатоцити нечітко контурувалися, нерідко розпадалися. Цілі пласти клітин перебували на

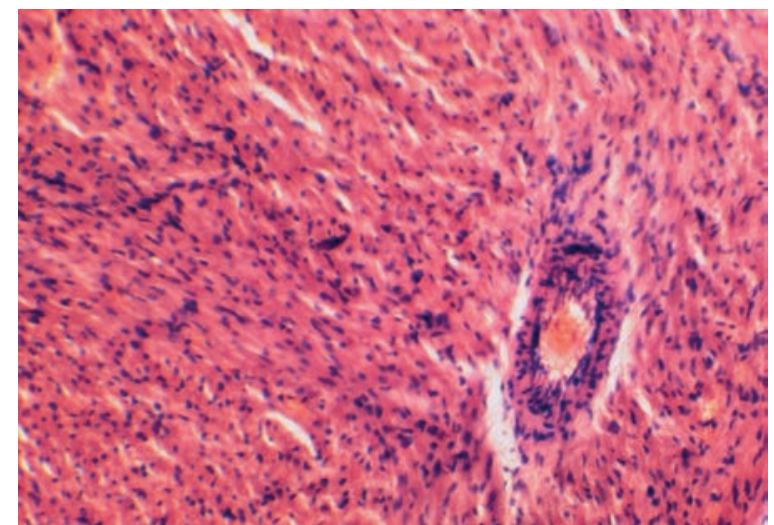

Рис. 10. Гістологічні зміни міокарда старого щура: склероз і клітинна інфільтрація стінки судини. Забарвлення гематоксиліном та еозином.

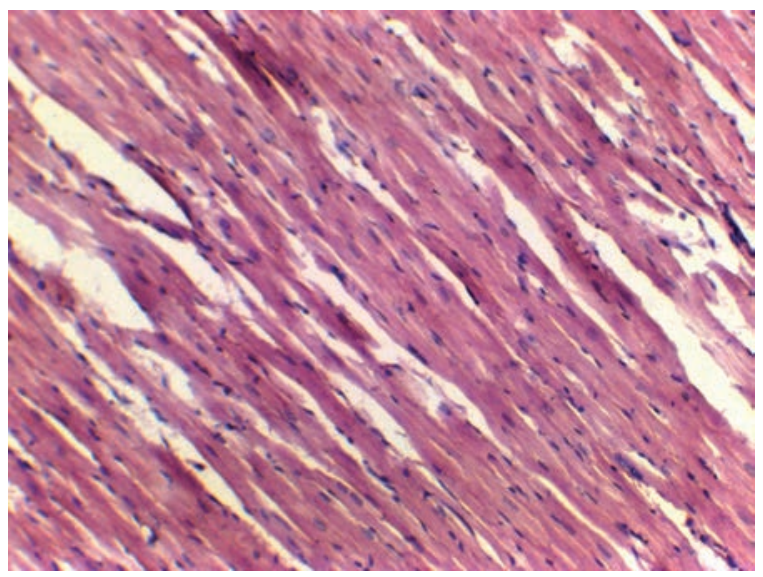

Рис. 11. Гістологічна структура міокарда старого щура на поздовжньому зрізі. Забарвлення гематоксиліном та еозином. Ок. 10. Об. 20.

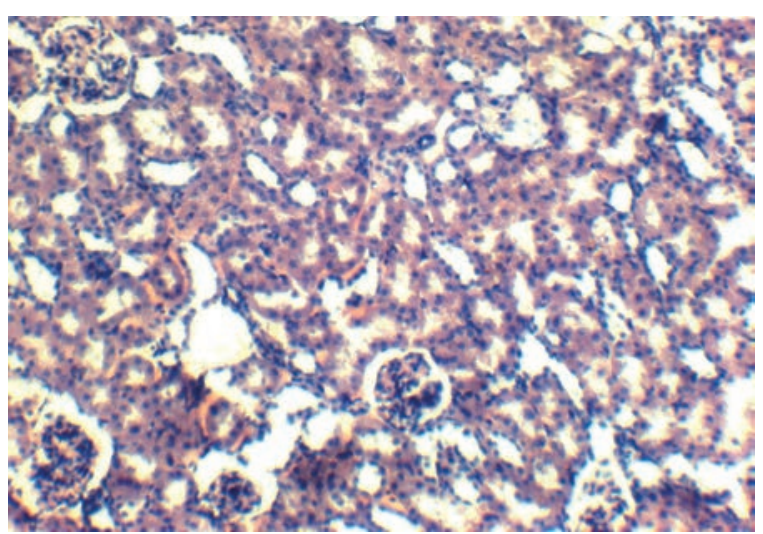

Рис. 12. Гістологічні зміни нирки старого щура. Забарвлення гематоксиліном та еозином. Ок. 10. Об. 20.

різних стадіях білкової дистрофії. Ядра лежали в центрі оптично порожніх клітин.

Введення ураженим щурам пептиду цистеїл-гістидил-тирозил-гістидил-ізолейцину зменшувало ступінь ушкоджень структурних компонентів тканин органів та сприяло перебігу регенераторних процесів.

Так, мікроскопічний аналіз міокарда 3-місячних щурів після корекції пептидом показав, що 
негативні структурні зміни, характерні для попереднього етапу експерименту, значно послаблювалися. Передусім виражено зменшувалися поширеність і частота патоморфологічних порушень. Кровонаповнення мікроциркуляторного русла ставало помірним та рівномірним. Такий есрект досягався за рахунок відновлення тонусу венозної ланки та послаблення констрикторних впливів на приносну ланку. Паралельно в позитивну сторону змінювалися реологічні властивості крові. Явища стазу зберігалися, але втрачали системний характер. У ділянках превалювання стазу виявляли внутрішньосудинну агрегацію еритроцитів (рис. 14).

У жодному випадку ми не спостерігали еритроцитарних екстравазатів. Однак нерідко стінки дрібних артерій та артеріол були потовщеними в результаті плазматичного просякання переважно внутрішньої оболонки та медії. Ендотелій у таких судинах злущувався на невеликих ділянках. Перивазальна строма й адвентиція набрякали. Слід відмітити, що набряк не набував поширеного характеру. В місцях відновлення кровотоку в мікросудинах набряку не спостерігали.

Завдяки покращенню мікроциркуляції позитивних змін зазнавав клітинний компонент. Кардіоміоцити в більшості випадків розміщувалися компактно. Межі клітин набували чіткості. Однак внутрішньоклітинний компонент мав сповільнені тенденції до відновлення. Цитоплазма часто зберігала мозаїчний характер, тому що нерівномірно вбирала барвник. На цьому тлі виявляли осередки еозинофрілії. Гетерогенності гістологічній картині надавали зміни зі сторони ядер, які ставали гіперхромними або мали вигляд кільця за рахунок маргінації хроматину. Поперечна посмугованість зберігалася, хоча нерідко слабо розрізнялася. Слід зазначити, що в жодному випадку ми не виявили виражених великоосередкових дегенеративних змін та повністю були відсутніми деструктивно-некротичні процеси.

Дослідження структурної організації тканини нирок молодих тварин після корекції пептидом також показало наявність суттєвих позитивних зрушень як стромальних, так і паренхіматозних компонентів (рис. 15). Якщо в уражених щурів найбільш яскраво проявлялися розлади кровообігу, то після корекції стан мікроциркуляції значно покращувався. Перш за все в жодному випадку ми не спостерігали гістологічної картини "шокової" нирки. Кровонаповнення строми кіркового та мозкового шарів набувало рівномірного характеру, хоча, як і в міокарді, виявляли стази та явища сладжу. На цих ділянках зберігався інтерстиціальний набряк. Гемодинаміка клубочків показувала дещо сповільнені позитив-

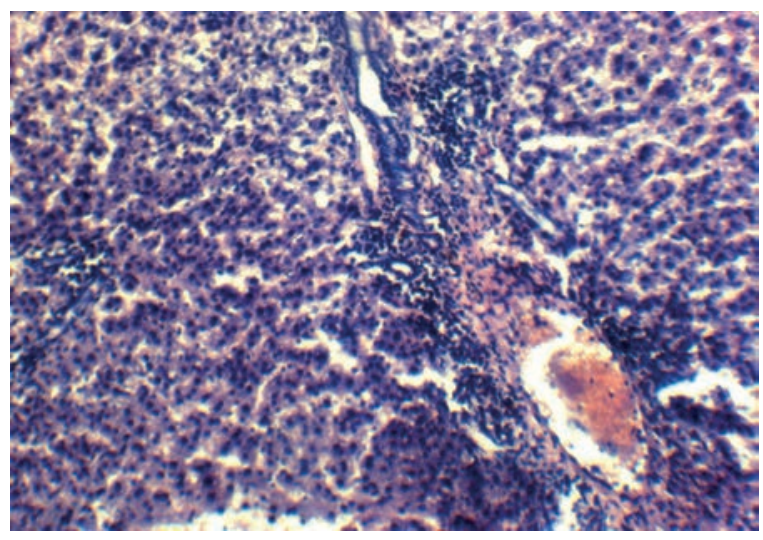

Рис. 13. Гістологічні зміни печінки старого щура. Забарвлення гематоксиліном та еозином. Ок. 10. Об. 20.

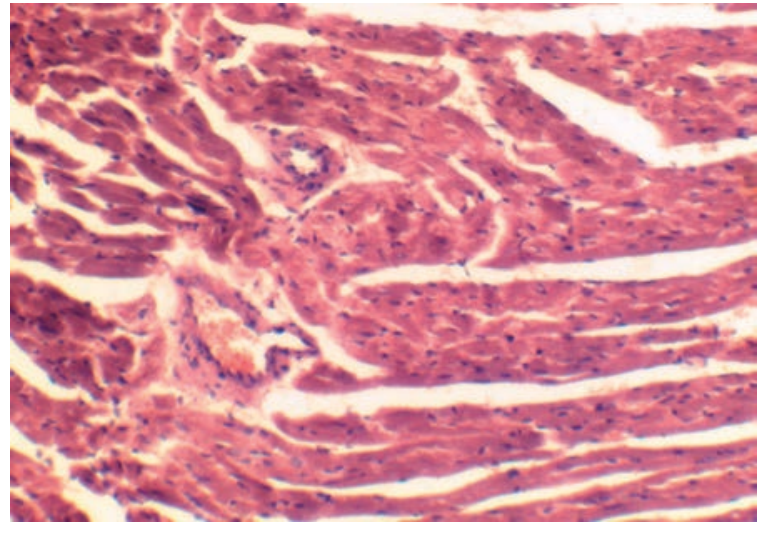

Рис. 14. Гістологічна структура міокарда 3-місячного щура після корекції пептидом цистеїл-гістидил-тирозилгістидил-ізолейцином. Плазматичне просякання судинних стінок, перивазальний набряк, пристінкова агрегація еритроцитів у венулі. Забарвлення гематоксиліном та еозином. $\times 100$

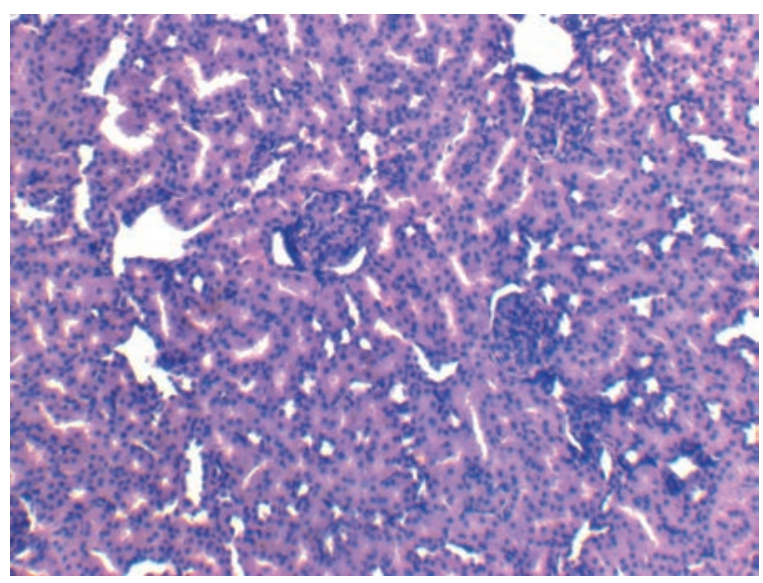

Рис. 15. Гістологічна структура нирки 3-місячного щура після корекції пептидом цистеїл-гістидил-тирозил-гістидилізолейцином. Набубнявіння епітеліоцитів звивистих канальців, набряк клубочків. Забарвлення гематоксиліном та еозином. $\times 100$.

ні зрушення. Кровонаповнення було нерівномірним як у різних тварин, так і в межах одного органа. Клубочки заповнювали весь просвіт капсули. Ми розцінювали це як прояв набряку мезангіуму. 
Коригувальний вплив пептиду позитивно позначився на стані паренхіматозного компонента нефрронів. Рівень морорологічних порушень суттєво знижувався. Епітеліоцити прямих канальців мозкового шару зберігали свою цілісність при наявності помірних дистробрічних змін. В епітеліальних клітинах дистальних та проксимальних звивистих канальців ступінь патологічних змін був дещо вищим, але без деструктивних ознак. Нерідко спостерігали апікальну десквамацію, зернисту дистрофрію та гетерогенні зміни ядер (рис. 15).

Гістологічне вивчення структури печінки 3-місячних щурів після кореції цистеїл-гістидил-тирозил-гістидил-ізолейцином показало аналогічну динаміку, виражено зменшувалася частота структурних порушень. У більшості випадків переважали слабо чи помірно виражені дистроорічні зміни гепатоцитів поряд із незміненими клітинами. Виявляли поля печінкової тканини, ідентичні з такими в контрольній групі тварин. У жодному випадку не спостерігали некрозів. Клітини зберігали свої тинкторіальні властивості. Переважали гепатоцити з гомогенною рівномірно забарвленою цитоплазмою, хоча гетерогенність самих клітин не була вираженою. Подекуди виявляли внутрішньоклітинні холестази. Ядра мали переважно округлу фрорму і чіткі контури. Однак зберігався їх поліморфізм, спостерігали ознаки пікнозу. З'являлися гіпертрофровані клітини з двома ядрами. Лімфоцитарна інфрільтрація була слабовираженою. Очевидно, позитивні зміни поєднувалися з покращенням кровопостачання печінкових часточок, що проявлялося зменшенням дистонічних проявів, набряку перисинусоїдальних просторів. Структура стінок судин портальних трактів була близькою до нормальних (рис. 16).

При корекції пептидом цистеїл-гістидил-тирозил-гістидил-ізолейцином у групі дорослих щурів під час гістологічного дослідження було виявлено комплекс однотипних та однонаправлених із молодими тваринами змін. Різниця полягала в поширеності та ступені вираження цих ознак. А саме в серці щурів стан мікрогемодинамічного русла в цілому мало відрізнявся від норми (рис. 17). Однак у поодиноких випадках чи в межах одного випадку ми спостерігали розлади гемодинаміки за типом паретичного венозного повнокров'я при зниженому кровонаповненні приносної ланки. Ендотелій зазнавав уже описаних вище змін, що сприяли набряку всіх стінок судин та периваскулярної проміжної тканини. Клітинні інфрільтрати спостерігали зрідка з незначною кількістю клітин, переважно лімфроцитів.

Відновлення відповідного кровотоку зумовило значне зменшення кількості ушкоджених кардіоміоцитів. У жодному випадку не було виявлено некротизованих чи некробіотично змінених клітин. Кардіоміоцити переважно зберігали компактне і впорядковане розміщення. Дистрофрічні зміни клітин були нерівномірно поширені по всьому органу. Поперечну посмугованість кардіоміоцитів спостерігали не завжди, а поліморфність ядер надавала неоднорідності клітинам (рис. 17).

При мікроскопічному дослідженні нирок 6-місячних тварин ми спостерігали відновлення більш адекватного, ніж у молодих щурів, кровонаповнення клубочків та судин строми обох шарів за умови корекції пептидом. Ознаки сповільненого кровотоку виявляли несистематично, але в ділянках збереженого венозного стазу відзначали також і стромальний набряк. Клубочки були чітко структуровані з вільним просвітом

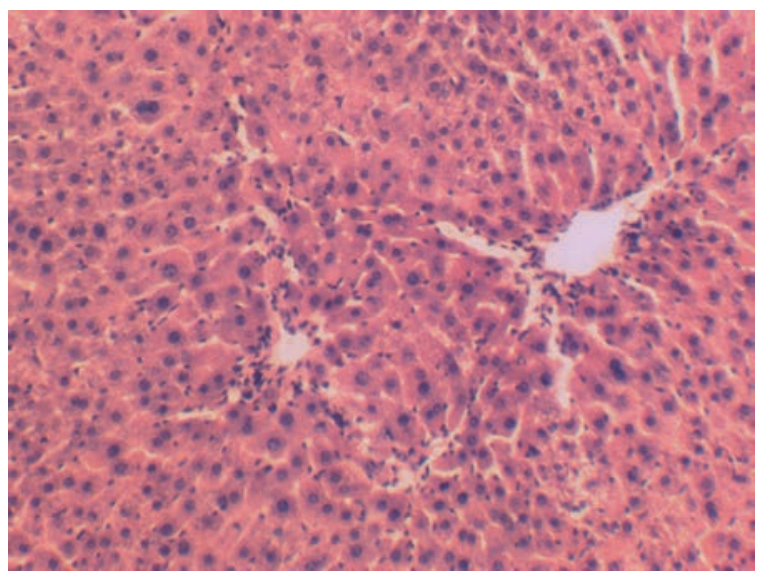

Рис. 16. Гістологічна структура печінки 3-місячного щура після корекції пептидом цистеїл-гістидил-тирозилгістидил-ізолейцином. Осередкові дистрофрічні зміни гепатоцитів і дискомплуксація балок на периферії часточок, ознаки регенерації. Забарвлення гематоксиліном та еозином. $\times 100$.

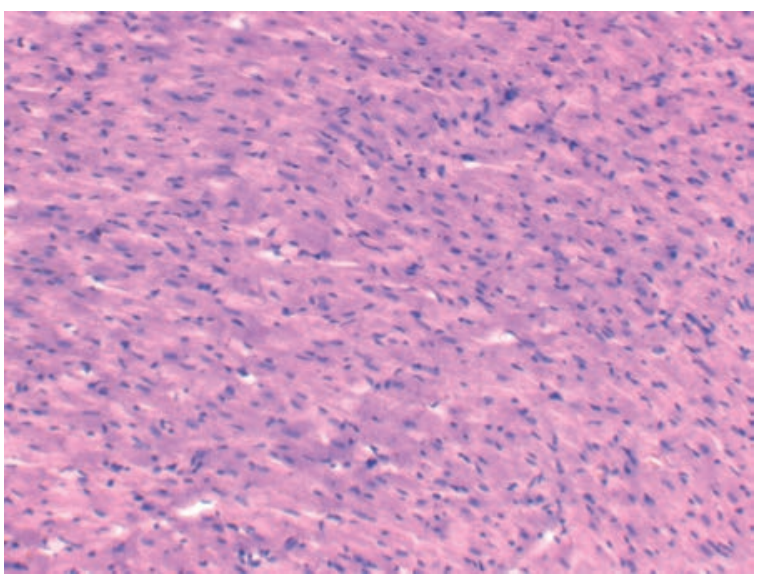

Рис. 17. Гістологічна структура міокарда 6-місячного щура після корекції пептидом цистеїл-гістидил-тирозилгістидил-ізолейцином. Компактне і впорядковане розміщення кардіоміоцитів, помірні нерівномірно виражені дистрофічні зміни. Ядра поліморфні. Забарвлення гематоксиліном та еозином. ×100. 
капсули Шумлянського - Боумена. Присутність ознак білкової дистрофрії не порушувала стратисрікації епітеліальної вистілки. У жодному випадку не спостерігали деструктивних змін базальної мембрани. Подібні зміни виявляли і в мозковому шарі досліджуваних нирок (рис. 18).

Позитивну динаміку морфологічних змін ми виявляли і в печінці. Слід сказати, що ці зміни були більш суттєвими, ніж у 3-місячних щурів. Чітко простежувалася гістоархітектоніка печінкових часточок. Розширювалися поля незмінених та малозмінених гепатоцитів. Збільшувалася частка регенеруючих клітин. У частині випадків гістологічна структура печінкової тканини відповідала нормі, в інших - дистрофічні зміни виявляли несистематично, зрідка зустрічалися групи клітин у стані балонної дистрофії та зі спустошеною цитоплазмою. Простори Діссе були помірно розширені. Портальні тракти здебільшого зберігали звичайну будову зі слабовираженою або відсутньою лімфрогістіоцитарною інфрільтрацією (рис. 19).

Мікроскопічне вивчення ступеня структурних змін внутрішніх органів старих тварин за умов коригувальної дії пептиду показало аналогічну позитивну динаміку, як і в молодих та дорослих щурів. Ці прояви зберігали свою неспецифічність, стереотипність та гетерогенність.

Так, під час гістологічного дослідження міокарда старих щурів при впливі пептиду було виявлено більшу кількість ділянок із незміненою гістоструктурою, що забезпечувалося покращенням стану судинного русла. Інтерстицій позитивно реагував на зниження рівня паретичного венозного повнокров'я - зменшувалися та зникали ознаки набряку проміжної сполучної тканини. Характерною в цій групі тварин була наявність вікових змін, які стосувалися перш за все стану судинних стінок. Регулярно виявляли артеріоли, зрідка й венули, з потовщеними стінками за рахунок проліферації в них колагенових волокон. Такі зміни сприяли пролонгації розладів кровообігу, хронічній ішемізації міокарда та склерозуванню. Тому, поряд із нормалізацією структурних компонентів міокарда, ми спостерігали проліферацію сполучної тканини навколо окремих кардіоміоцитів та їх груп. Проте зберігалися нерівномірно виражені дистрофрічні зміни клітин. Значно слабшими, порівняно 3 молодими та дорослими особинами, були прояви компенсаторних процесів та наростали атрофрічні явища (рис. 20).

Подібні тенденції виявляли і в печінці. У стромі портальних трактів печінки також незначно збільшувалася частка сполучної тканини. Деструктивні зміни гепатоцитів були відсутні, але відзначали нерівномірно виражені дистрофрічні

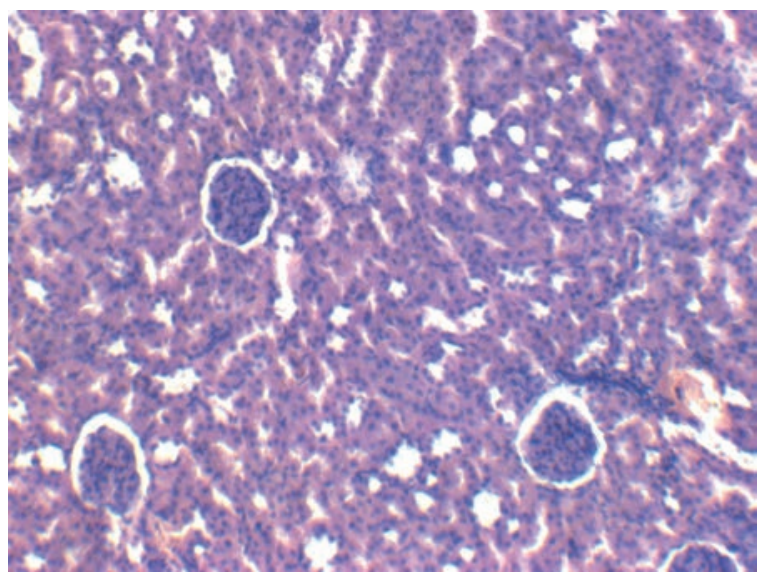

Рис. 18. Гістологічна структура нирки 6-місячного щура після корекції пептидом цистеїл-гістидил-тирозил-гістидилізолейцином. Чітко структуровані клубочки, вільний просвіт капсули Шумлянського - Боумена, помірна білкова дистрофрія епітеліоцитів звивистих канальців. Забарвлення гематоксиліном та еозином. $\times 100$.

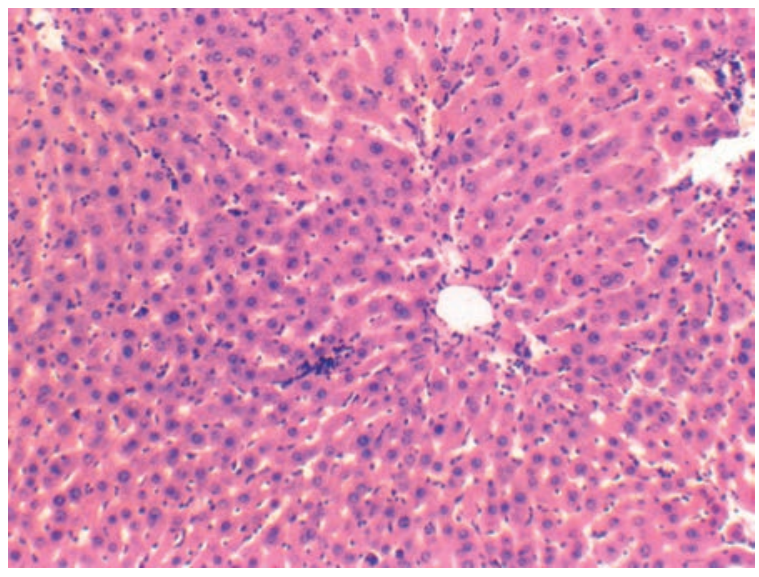

Рис. 19. Гістологічна структура печінки 6-місячного щура після корекції пептидом цистеїл-гістидил-тирозилгістидил-ізолейцином. Чітко виражена структура часточок, помірне розширення просторів Діссе, дрібні лімфоцитарні інфільтрати. Забарвлення гематоксиліном та еозином. $\times 100$.

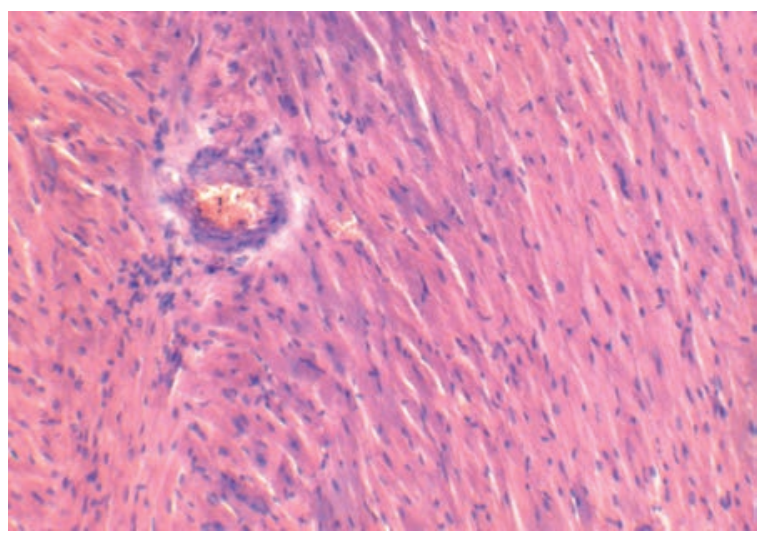

Рис. 20. Гістологічна структура міокарда 24-місячного щура після корекції пептидом цистеїл-гістидил-тирозилгістидил-ізолейцином. Проліфрерація колагенових волокон в адвентиції дрібної артерії та периваскулярному просторі. Сладж еритроцитів, дистрофрічні зміни кардіоміоцитів. Забарвлення гематоксиліном та еозином. $\times 160$. 
прояви різної інтесивності. Слід зауважити, що в цей період спостерігали також і ознаки регенерації гепатоцитів - з'являлися гіпертрофровані клітини з двома ядрами (рис. 21).

Судинне русло нирок щурів у більшості випадків мало відрізнялося від структурно-фрункціонального стану судин нирок тварин контрольної групи. Епітелій звивистих канальців структурно був гетерогенним. Поряд із незміненими виявляли клітини із зернистою чи глибковою цитоплазмою, подекуди - $з$ апікальною десквамацією (рис. 22). Некротичних змін нефроцитів ми не спостерігали. Склеротичні зміни судин артеріального типу були слабовираженими.

Отже, позитивна динаміка змін структурних компонентів у 24-місячних щурів була слабшою порівняно з групами молодих та дорослих тварин. Особливо це стосувалося компенсаторних проявів. На тлі вікових змін зберігалися дезорганізація та, частково, деструкція паренхіматозних компонентів на фоні достатньо виражених розладів мікрогемодинаміки.

ВИСНОВКИ. 1. Токсичне ураження Плюмбуму ацетатом, Купруму сульфратом та гліфосатом викликає комплекс змін, властивих загальнотоксичним впливам і зумовлених як прямою токсичною дією речовин, які вводять, так і гіпоксичним ушкодженням внаслідок тяжких розладів органної мікрогемодинаміки.

2. Морфологічна сутність таких змін полягає в розвитку різного ступеня дистрофрічних та деструктивних процесів паренхіматозних компонентів органів на тлі мікроциркуляторних порушень. Найбільш виражені ураження органів при дії ксенобіотиків виявлено в молодих і старих тварин.

3. Застосування пептиду цистеїл-гістидил-тирозил-гістидил-ізолейцину при інтоксикації Плюмбуму ацетатом, Купруму сульсратом та гліфосатом зменшує ступінь ушкоджень структурних компонентів міокарда, нирок і печінки, сприяє активному перебігу регенераторних процесів та їх відносній нормалізації.

4. Позитивний вплив застосування пептиду для корекції змін, викликаних інтоксикацією Плюмбуму ацетатом, Купруму сульфратом та

\section{СПИСОК ЛІТЕРАТУРИ}

1. Ahamed M. Environmental lead toxicity and nutritional factors / M. Ahamed, M. K. J. Siddiqui // Clin. Nutr. - 2007. - 26 (4). - P. 400-408.

2. Effects of subchronic exposure via drinking water to a mixture of eight water contaminating metals: A biochemical and histopathological study in male rats /

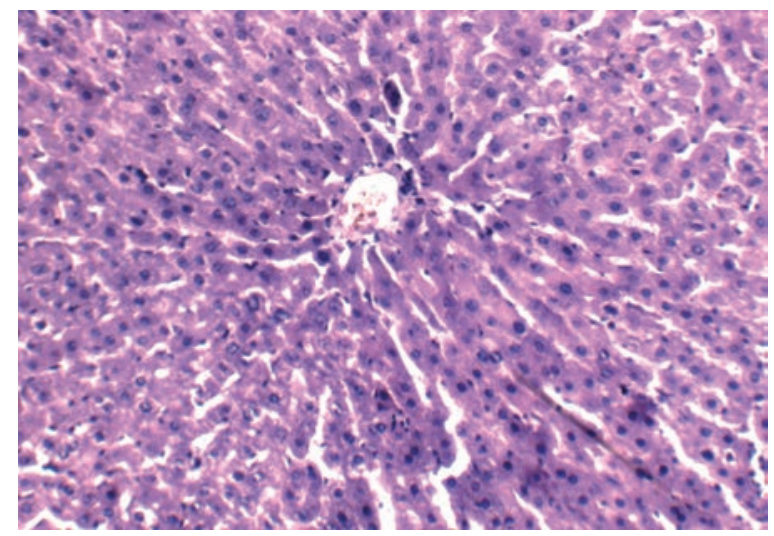

Рис. 21. Гістологічна структура печінки 24-місячного щура після корекції пептидом цистеїл-гістидил-тирозилгістидил-ізолейцином. Дистрофрічні зміни гепатоцитів на периферії часточки. Поодинокі двох'ядерні клітини. Забарвлення гематоксиліном та еозином. ×160.

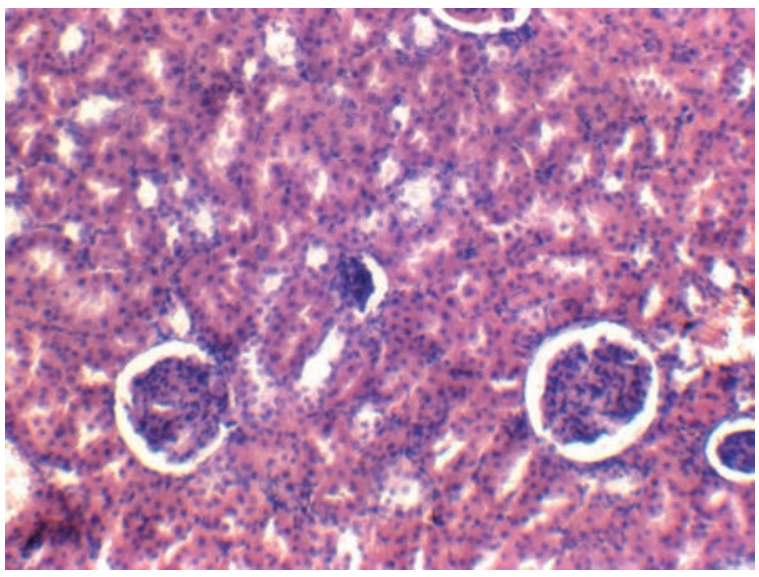

Рис. 22. Гістологічна структура нирки 24-місячного щура після корекції пептидом цистеїл-гістидил-тирозил-гістидилізолейцином. Дистросрічні зміни епітеліоцитів різного ступеня вираження 3 осередками апікальної десквамації. Забарвлення гематоксиліном та еозином. $\times 160$.

гліфросатом, не значний. Найкращу динаміку відновних процесів виявлено в дорослих тварин. Мікроскопічний аналіз показав, що структурні компоненти міокарда, печінки та нирок у цій віковій групі максимально наближаються до нормальних.

Перспективи подальших досліджень. Плануємо вивчити вплив пептидів на ліпідний обмін у щурів при комбінованій дії Купруму сульфрату, Плюмбуму ацетату та раундапу.

S. H. Jadhav, S. N. Sarkar, R. D. Patil, H. C. Tripathi // Arch. Environ. Con. Toxicol. - 2007. - 53 (4). - P. 667677.

3. Vaziri N. D. Lead-induced hypertension: Role of oxidative stress / N. D. Vaziri, D. A. Sica // Curr. Hyper. Rep. J. - 2004. - No. 6. - P. 314-320. 
4. Neurotoxicity of lead. Hypothetical molecular mechanisms of synaptic function disorders. Neurol. I I. Baranowska-Bosiacka, I. Gutowska, M. Rybicka [et al.] // Neurochir. Pol. J. -2012. -46 (6). - P. 569-578.

5 . Failure of recovery from lead induced hepatoxicity and disruption of erythrocyte antioxidant defence system in wistar rats / T. O. Omobowale, A. A. Oyagbemi, A. S. Akinrinde [et al.] // Environ. Toxicol. Pharm. 2014. No. 37 (3). - P. 1202-1211.

6. Barros R. C. H. Cardiovascular responses to chemoreflex activation with pottassium cyanide or hypoxic hypoxia in awake rats / R. C. H. Barros, L. G. H. Bonagamba, Okamoto- R. Canesin. - Autonomic Neuroscience: Basic, and Clinical. - 2002. - 97. - P. 110-115.

\section{REFERENCES}

1. Ahamed, M., \& Siddiqui, M.K.J. (2007). Environmental lead toxicity and nutritional factors. Clin. Nutr., 26 (4), 400-408.

2. Jadhav, S.H., Sarkar, S.N., Patil, R.D., \& Tripathi, H.C. (2007). Effects of subchronic exposure via drinking water to a mixture of eight water contaminating metals: A biochemical and histopathological study in male rats. Arch. Environ. Con. Toxicol., 53 (4), 667-677.

3. Vaziri, N.D., \& Sica, D.A. (2004). Lead-induced hypertension: Role of oxidative stress. Curr. Hyper. Rep. J., 6, 314-320.

4. Baranowska-Bosiacka, I., Gutowska, I., Rybicka, M., Nowacki, P., \& Chlubek, D. (2012). Neurotoxicity of lead. Hypothetical molecular mechanisms of synaptic function disorders. Neurol. Neurochir. Pol. J., 46 (6), 569-578.

5. Omobowale, T.O., Oyagbemi, A.A, \& Olopade, J.O. (2014). Failure of recovery from lead induced hepatoxicity and disruption of erythrocyte antioxidant defence system in wistar rats. Environ. Toxicol. Pharm., 37 (3), 1202-1211.
7. Про захист тварин від жорстокого поводження : Закон України від 21.02.2006 р. № 3447-IV.

8. Науково-практичні рекомендації з утримання лабораторних тварин та роботи з ними / Ю. М. Кожем'якін, О. С. Хромов, М. А. Філоненко, Г. А. Сайоретдінова. - К. : Авіцена, 2002. - 155 с.

9. European convention for the protection of vertebrate animals used for experimental and other scientific purposes. - Council of Europe. Strasbourg, 1986. No. 123. $-52 \mathrm{p}$.

10. Сапожников А. Г. Гистологическая и микроскопическая техника: руководство / А. Г. Сапожников, А. Е. Доросевич. - Смоленск : САУ, 2000. - 476 с.

6.Barros, R.C.H., Bonagamba, L.G.H., \& Machado, B.H. (2002). Cardiovascular responses to chemoreflex activation with pottassium cyanide or hypoxic hypoxia in awake rats. Autonomic Neuroscience: Basic, and Clinical, 97, 110-115.

7. Zakon Ukrainy "Pro zakhyst tvaryn vid zhorstokoho povodzhennia" vid 21.02.2006 r., No 3447 [The Law of Ukraine "On the Protection of animals from ill-treatment" of 02.21. 006, No. 3447] [in Ukrainian].

8. Kozhemiakin, Yu.M., Khromova, O.S., \& Filonenko, M.A. (2002). Naukovo-praktychni rekomendatsii z utrymannia laboratornykh tvaryn ta robota z nymy [Scientific and practical recommendations for the maintenance of laboratory animals and work with them]. Kyiv: Avitsena [in Ukrainian].

9. (1986). European convention for the protection of vertebrate animals used for experimental and other scientific purposes Council of Europe. Strasbourg.

10. Sapozhnikov, A.G., \& Dorosevich, A.E. (2000). Gistolohgicheskaya i mikroskopicheskaya tekhnika: rukovodstvo [Histological and microscopic technique: a guide]. Smolensk: SAU [in Russian].

\section{МОРФОЛОГИЧЕСКИЕ ИЗМЕНЕНИЯ В ОРГАНАХ КРЫС ПРИ КОМБИНИРОВАННОМ ДЕЙСТВИИ СОЛЕЙ ТЯЖЕЛЫХ МЕТАЛЛОВ И ФОСФОРОРГАНИЧЕСКИХ ПЕСТИЦИДОВ}

\section{Резюме}

Вступление. Отравление свинцом опасно для здоровья населения. Свинец и его соединения используют в промышленности для изготовления красок, эмалей и др., поэтому одним из основных путей попадания свинца в организм человека является вдыхание пыли и дыма его соединений. Свинец проявляет иммунотоксичность, вызывает поражение печени, почек, органов дыхания, кровеносной и нервной систем.

Цель исследования - изучить влияние ацетата свинца, сульфрата меди и глифросата в фрорме раундапа на морфологические изменения в тканях сердца, почек и печени крыс разного возраста.

Методы исследования. Опыты проводили на лабораторных нелинейных белых крысах-самцах трех возрастных периодов: неполовозрелых (молодых массой 70-90 г и в возрасте 1-3 мес.), половозрелых 
(взрослых массой 170-210 г и в возрасте 5-8 мес.), старых (массой 250-300 г и в возрасте 20-24 мес.), которым внутрижелудочно в течение 30-ти дней вводили водные растворы ацетата свинца, сульфата меди и глифосата (в форме гербицида раундапа) и выполняли коррекцию пептидом цистеил-гистидилтирозил-гистидил-изолейцином. Гистологические препараты изучали после окраски их гематоксилином и эозином с помощью светового микроскопа OLYMPUS "CX 21".

Результаты и обсуждение. Установлено, что введение животным водных растворов ацетата свинца, сульфата меди и раундапа влияет на фрункции их органов. Во время морфрологических исследований было выявлено клеточные поражения в тканях сердца, почек и печени крыс, вызванные введением ксенобиотиков. Гистологические поражения включали воспаление, гиперхромную анемию, полиморфрную инфильтрацию клубочков и клеточную дегенерацию почек и печени. Наблюдали дистрофию паренхиматозных клеток, некротические процессы и застойные явления в сердче, почках и печени всех подопытных животных.

Вывод. Введение ацетата свинца, сульфрата меди и глифосата в фрорме раундапа вызывает морфологчческие изменения в тканях сердца, почек и печени крыс.

КЛЮЧЕВЫЕ СЛОВА: морфоффункциональные свойства; ацетат свинца; сульфат меди; глифосат; хроническое действие; крысы.

Ye. B. Dumukhalska

\section{THE MORPHOLOGICAL CHANGES IN ORGANS OF RATS UNDER THE CONDITIONS OF COMPLEX PERSISTENT EFFECT OF HEAVY METAL SALTS AND PHOSPHORORGANIC PESTICIDES}

\section{Summary}

Introduction. Lead poisoning is a major public health risk. Lead is an immunotoxicant, it has reproductive toxicity, liver toxicity. Lead and its compounds has many uses in industry for manufacturing paints, enamels, and others. The major hazard in industry arises from the inhalation of dust and fume of lead compounds.

The aim of the study - to research the effect of the lead acetate, the copper sulfate, the glyphosate (in herbicide Roundup) on morphological changes on the rat heart, kidneys, and liver tissue.

Research Methods. Experiments were performed on lab nonlinear white male rats of three age periods: puberty (youth, 70-90 g body weight and 2 to 3 months age); mature (average, weighing 170-210 g and aged 5-8 months) and aged rats processes in which catabolic processes prevail over anabolic (body weight 250-300 $\mathrm{g}$ and aged 20-24 months), which were injected intragastrically for 30 days with the lead acetate, the copper sulfate, the glyphosate (in herbicide Roundup) and correction for peptide. Rat tissue sections were prepared and observed under a light microscope for morphological changes. The study of histological preparations was performed after coloring with hematoxylin and eosin using a light microscope OLYMPUS CX 2.

Results and Discussion. We determined that introduction to animals of water solutions of lead acetate, copper sulfate and Roundup influences the functions of their organs. The morphological examinations revealed cellular lesions in the heart, kidneys, and liver tissue of rats caused by xenobiotics administration. The histological lesions included inflammation, hyperchromic anemia, polymorph infiltration of the glomeruli, and cellular degeneration kidneys, and liver. It was observed included symptoms of the hepatocytes', necrosis and degeneration associated with infiltration in the liver of all experimental animals.

Conclusion. The effect of the lead acetate, the copper sulfate, the glyphosate (in herbicide Roundup) caused morphological changes of heart tissue, kidneys tissue, and liver tissue in rats. rats.

KEY WORDS: morpho-functional properties; lead acetate; copper sulfate; glyphosate; chronic effects;

Отримано 30.01.19

Адреса для листування: Є. Б. Дмухальська, Тернопільський державний медичний університет імені І. Я. Горбачевського, майдан Волі, 1, Тернопіль, 46001, Україна, e-mail: dmukhalska@tdmu.edu.ua. 